\title{
Nature-Based Resilience: A Multi-Type Evaluation of Productive Green Infrastructure in Agricultural Settings in Ontario, Canada
}

\author{
Vidya Anderson ${ }^{1, *(1)}$ and William A. Gough ${ }^{1,2}$ \\ 1 Climate Lab, Department of Physical and Environmental Sciences, University of Toronto Scarborough, \\ Toronto, ON M1C 1A4, Canada; william.gough@utoronto.ca \\ 2 Department of Physical and Environmental Sciences, University of Toronto Scarborough, \\ Toronto, ON M1C 1A4, Canada \\ * Correspondence: vidya.anderson@utoronto.ca
}

check for updates

Citation: Anderson, V.; Gough, W.A. Nature-Based Resilience: A Multi-Type Evaluation of Productive Green Infrastructure in Agricultural Settings in Ontario, Canada. Atmosphere 2021, 12, 1183. https:// doi.org/10.3390/atmos12091183

Academic Editor: Simone Orlandini

Received: 30 June 2021

Accepted: 8 September 2021

Published: 14 September 2021

Publisher's Note: MDPI stays neutral with regard to jurisdictional claims in published maps and institutional affiliations.

Copyright: (c) 2021 by the authors. Licensee MDPI, Basel, Switzerland. This article is an open access article distributed under the terms and conditions of the Creative Commons Attribution (CC BY) license (https:/ / creativecommons.org/licenses/by/ $4.0 /)$.

\begin{abstract}
Nature-based solutions such as green infrastructure present an opportunity to reduce air pollutant concentrations and greenhouse gas emissions. This paper presents new findings from a controlled field study in Ontario, Canada, evaluating the impact of productive applications of green infrastructure on air pollution and carbon dioxide concentrations across different agricultural morphologies compared to other non-productive applications. This study demonstrates that productive green infrastructure applications are as beneficial as non-productive applications in reducing ozone, nitrogen dioxide, and carbon dioxide concentrations. Nature-based solutions present an opportunity to build climate resilience into agricultural systems through supply-side mitigation and adaptation. The implementation of productive green infrastructure could be a viable agricultural practice to address multiple climate change impacts.
\end{abstract}

Keywords: green roofs; urban agriculture; tree-based intercropping; agroforestry; food security

\section{Introduction}

Approximately 25 percent of global greenhouse gas (GHG) emissions can be attributed to agricultural production [1]. Agricultural production accounts for approximately 10 percent of GHG emissions in Ontario, Canada, with emissions remaining stable since 1990 at approximately 10 megatons [2]. Anthropogenic activities continue to change the atmospheric and surface conditions of the Earth, with significant generation of GHG emissions occurring in urban areas from deforestation, land use development, agricultural production, energy generation, vehicular and freight transportation, heavy industry, and buildings [3]. While agriculture is a significant contributor to global GHG emissions, the changing climate also has impacts upon agricultural production. Climate change is impacting agriculture through rising temperatures, changing precipitation patterns, and increased frequency of extreme events.

Traditional air pollutant sources can also be sources of GHGs and particulate matter that influence climate. Solar and terrestrial interactions occur between these air pollutants and radiation. These interactions impact on the Earth's energy balance, leading to changes in climate $[4,5]$. Conversely, air pollution is also influenced by climate change as a result of changes to the intensity, duration, and frequency of persistent weather events, heat waves, precipitation, and other meteorological phenomena [5-10].

The application of green infrastructure delivers a nature-based solution to reduce air pollution and to bridge the gap between supply-side climate change mitigation and adaptation in agricultural settings. The International Union for Conservation of Nature (IUCN) defines nature-based solutions as "actions to protect, sustainably manage, and restore natural or modified ecosystems, that address societal challenges effectively and adaptively, simultaneously providing human well-being and biodiversity benefits" [11]. 
Nature-based solutions describe the five categories of ecosystem-based approaches, including green infrastructure [11-13]. Productive (i.e., food-producing) green infrastructure provides an opportunity for agriculture to mitigate its contributions to climate change and effectively adapt to its consequences. While agricultural production systems with these attributes are rare, the adoption of productive green infrastructure is essential to climate-resilient agricultural practices in the future.

\section{Literature Review}

Green infrastructure is broadly defined as inter-connected networks of natural and constructed green space, providing various non-provisioning and provisioning ecosystem services across different morphologies. As illustrated in Figure 1, productive green infrastructure can be categorized into three areas including green roofs, urban agriculture systems, and tree-based intercropping systems [14-19].

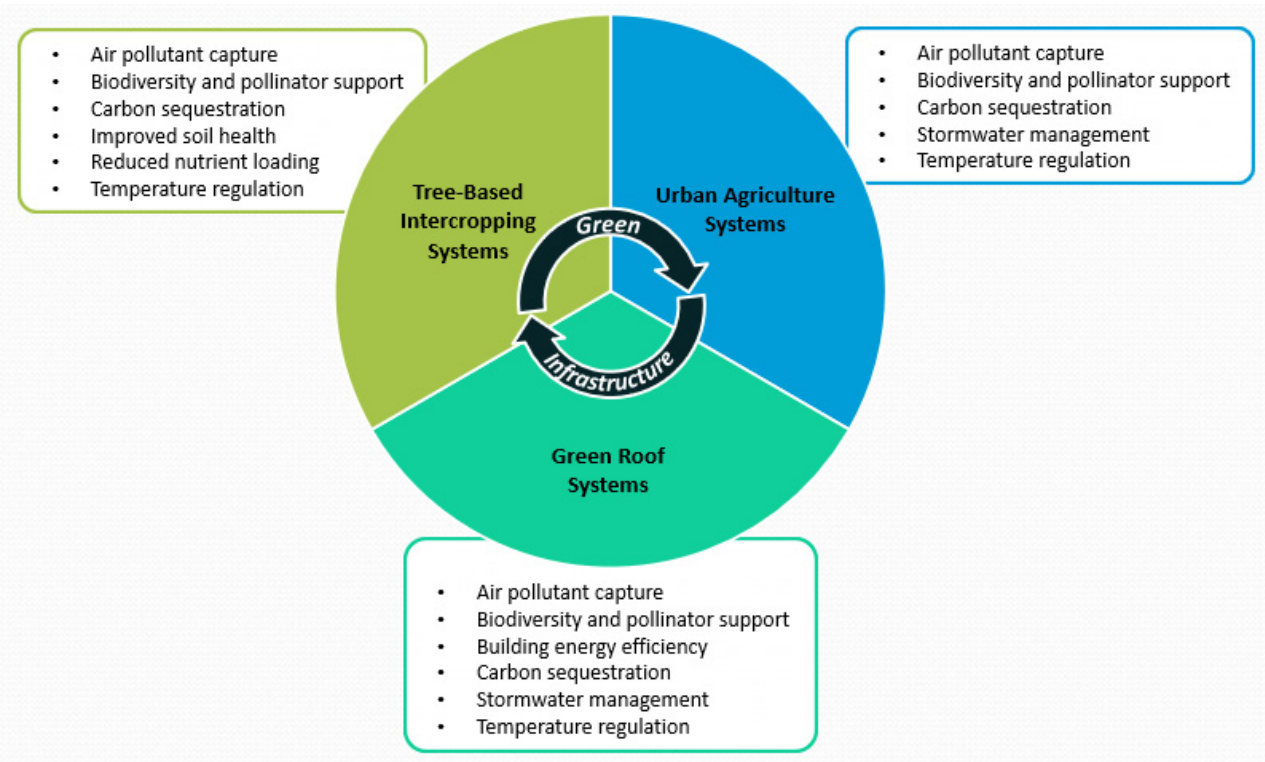

Figure 1. Green infrastructure form and function [14-19].

Green infrastructure as a supply-side intervention can contribute to climate change mitigation in agricultural systems by sequestering carbon in soils and biomass, and by decreasing emissions intensity within sustainable production systems [20-22].

As a supply-side intervention, green infrastructure can contribute to climate change adaptation by increasing soil organic matter and providing erosion control [21-23]. Green infrastructure can reduce flood risk, runoff, and nutrient loading by providing water storage during rainfall events and reducing overland flows. Stormwater management varies with each green infrastructure application and is influenced by factors including location, proximity to impervious surfaces, depth of soil or substrate, and type and ratio of vegetation. Green roofs reduce stormwater runoff from 50 to 100 percent depending on the depth of the substrate, roof slope, and plant species [24]. Tree-based intercropping systems reduce runoff and nutrient loading from agricultural fields to nearby water bodies by providing a natural buffer [25]. Urban agriculture systems reduce flood risk, runoff, and nutrient loading by minimizing impervious surfaces, retaining stormwater, and increasing infiltration [26].

As a supply-side intervention for climate change adaptation, green infrastructure can enhance biodiversity and provide pollinator habitats, essential in modern industrial agriculture. In addition, green infrastructure provides habitats for biological control agents that prey on crop pests, wherein plants themselves are used to diversify crops and chemically repel pests $[27,28]$. This is accomplished by visually camouflaging crops and 
diluting attractive stimuli [28]. Provision of biodiversity and pollinator support varies with each green infrastructure application and is influenced by factors including climate, location, plant diversity, depth of soil or substrate, and type and ratio of vegetation. Treebased intercropping systems improve soil health, increasing bird and insect diversity and earthworm distribution $[29,30]$. Tree-based intercropping systems also reduce the ecological impacts of agricultural production by creating more bio-diverse and sustainable land use systems $[20,29,30]$.

Urban agriculture systems also support pollinator and bird habitats [26]. Green roofs convert underutilized space to provide supportive habitats for various insect species, as well as space for nesting birds, native avian communities, urban wildlife, and pollinators [31,32]. Green roofs have also been shown to provide roosts and foraging habitats for urban bats [32]. Green roofs with greater plant diversity and proximity to other green space within the surrounding landscape have also been shown to provide supportive habitats to native bees [33].

In addition to improving croplands, green infrastructure can reduce the food miles and carbon footprint associated with conventional agriculture through local food production and distribution [16-19]. It can also reduce pressures on conventional agriculture and improve food security when large-scale agricultural production is affected by weather variation [16-19]. Productive (i.e., food-producing) green infrastructure in urban areas can also increase food security for vulnerable populations [19].

As a supply-side intervention for climate change mitigation, vegetation in different applications of green infrastructure can capture both gaseous and particulate matter pollution [28]. Removal of air pollutants occurs through absorption by leaf pores (stomata) and surfaces. It also occurs through adherence to plant surfaces [34]. Air pollutants are removed through chemical reactions on the plant's surface when precipitation occurs. Dry deposition occurs when air pollutants are removed by vegetation without precipitation [28]. Levels of abatement vary with the type of green infrastructure. Influencing factors include location, air flows, physical dimension, type and ratio of vegetation, and seasonal variation.

Air quality is affected by green infrastructure through deposition and immobilization of local air pollutants such as ozone and particulate matter [35-41]. Green infrastructure has also been shown to be effective in removing ozone, nitrogen dioxide, and particulate matter [15,35,37-43]. Studies have shown reductions in ozone as high as 16 percent and reductions in nitrogen dioxide as high as 9 percent from the application of trees and shrubs across the United States $[35,40]$. Average reductions of 4 percent in ozone and 3 percent in nitrogen dioxide from the application of urban forestry and vegetation have also been demonstrated across Canadian cities [35,40]. Studies have shown reductions in nitrogen dioxide air pollution of 13 percent from the application of urban forestry in New York City and as high as 45 percent from the application of urban trees in Portland [37,38]. While trees have demonstrated the highest uptake of air pollutants, continuity of form and tree size affect performance [40,44,45].

With extensive implementation, green roofs have also been shown to reduce air pollution [46-48]. Reductions in ozone of 52 percent and nitrogen dioxide of 27 percent have been demonstrated with the application of non-productive green roofs [42]. Factors influencing efficacy include configuration, wind flows, and orientation and geometry of the streetscape [40,48-51].

Green infrastructure can behave as a supply-side climate change mitigation intervention, by providing carbon sequestration capacity and reducing the carbon footprint of both urban and peri-urban agricultural landscapes. Green infrastructure removes carbon dioxide from the atmosphere through photosynthesis during daylight hours, while a subsequent release of carbon dioxide occurs through respiration at nighttime with additional carbon uptake occurring through soil and below-ground biomass [52]. Carbon sequestration varies with different types of green infrastructure, influenced by climate, location, air flow, type and ratio of vegetation, depth of soil or substrate, soil health, and landscape management. Green roofs sequester carbon in the vegetated layer and organic substrate [53]. Green roofs 
have been shown to lower carbon dioxide concentrations by as much as 2 percent in urban areas [54]. Carbon sequestration occurs through use of different plant varietals, including herbaceous perennials, grasses, vegetables, and herbs [53]. Roofs with deeper substrates sequester more carbon [53].

Retention of carbon stored in wood can last for many years and even centuries in a live tree. Carbon storage in leaves, greenery, and fine roots has a much shorter retention time [55]. Tree-based intercropping systems are effective in providing carbon sequestration capacity, compared to conventional systems, due to their ability to store carbon in permanent tree components and greater sequestration capacity [29]. Tree-based intercropping systems can sequester carbon because of increased carbon storage in the trees' biomass, slower decomposition of litter, and stabilization of soil organic carbon [56,57]. Conventional systems demonstrate lower soil organic carbon content than tree-based intercropping systems [30].

As shown in Figure 1, productive applications of green infrastructure include three types: green roofs, urban agriculture systems, and tree-based intercropping systems. Green roofs can be categorized as extensive or intensive. Extensive green roofs weigh less because of shallower depth and can allow for sloped roof installation. Intensive green roofs have a deeper soil layer and more plant variety in the vegetative layer [58]. Urban agriculture systems include growing roofs, rooftop gardens, market gardens, community gardens, and micro gardens $[26,59]$. Tree-based intercropping systems can be characterized as agricultural lands where trees or shrubs are interspersed with crops [20]. It is unclear whether these types of productive green infrastructure are as effective for air pollution abatement or GHG emissions reductions as non-productive green infrastructure systems. Green infrastructure tends to be applied in urban settings and infrequently used in rural settings.

The objectives of this study were to assess the potential of multiple productive green infrastructure applications within the three categories shown in Figure 1, to reduce ozone, nitrogen dioxide, and carbon dioxide concentrations across different agricultural morphologies in Ontario, Canada regardless of location, geography, or land use type, compared to non-productive green infrastructure applications.

\section{Methods}

The Anderson and Gough (2020) field study undertook a data collection campaign across various productive and non-productive applications of green infrastructure. Productive applications included green roof systems, urban agriculture systems, and tree-based intercropping systems. Non-productive applications included green roof systems, green wall systems, and urban forestry and vegetation systems. The data collection campaign was undertaken to measure the potential of green infrastructure to reduce ozone, nitrogen dioxide, and carbon dioxide concentrations, using portable air quality monitors for the period of June to October 2017 [15]. The methodology is described here for the reader's convenience.

The productive green infrastructure sites from the field study [15] were selected to be representative of the three green infrastructure categories and different agricultural morphologies as shown in Figure 2. Of these sites, one contained multiple applications of green infrastructure. The three sites selected for the field study included: (1) the rooftop fruit and vegetable garden located at the Instructional Centre building on the University of Toronto campus in suburban Scarborough; (2) the vegetable growing roof, extensive green roof, green wall, and rooftop medicine garden located at the Carrot Common in east Toronto; and (3) the tree-based intercropping system located at the Guelph Agroforestry Research Station on the University of Guelph campus, a site considered either peri-urban or rural.

As shown in Figure 2, the site at the Guelph Agroforestry Research Station is located within the rural area of Guelph among extensive farmlands and rural residential properties. The Carrot Common site is located east of the Toronto downtown core in a highly urbanized area of mixed low-rise commercial and residential buildings. The University of Toronto site, located in Scarborough, is an eastern suburb of the city characterized by mixed residential, institutional, commercial, and industrial buildings. These range from single- 
story family dwellings to high-rise apartments and low-rise commercial and industrial building developments.

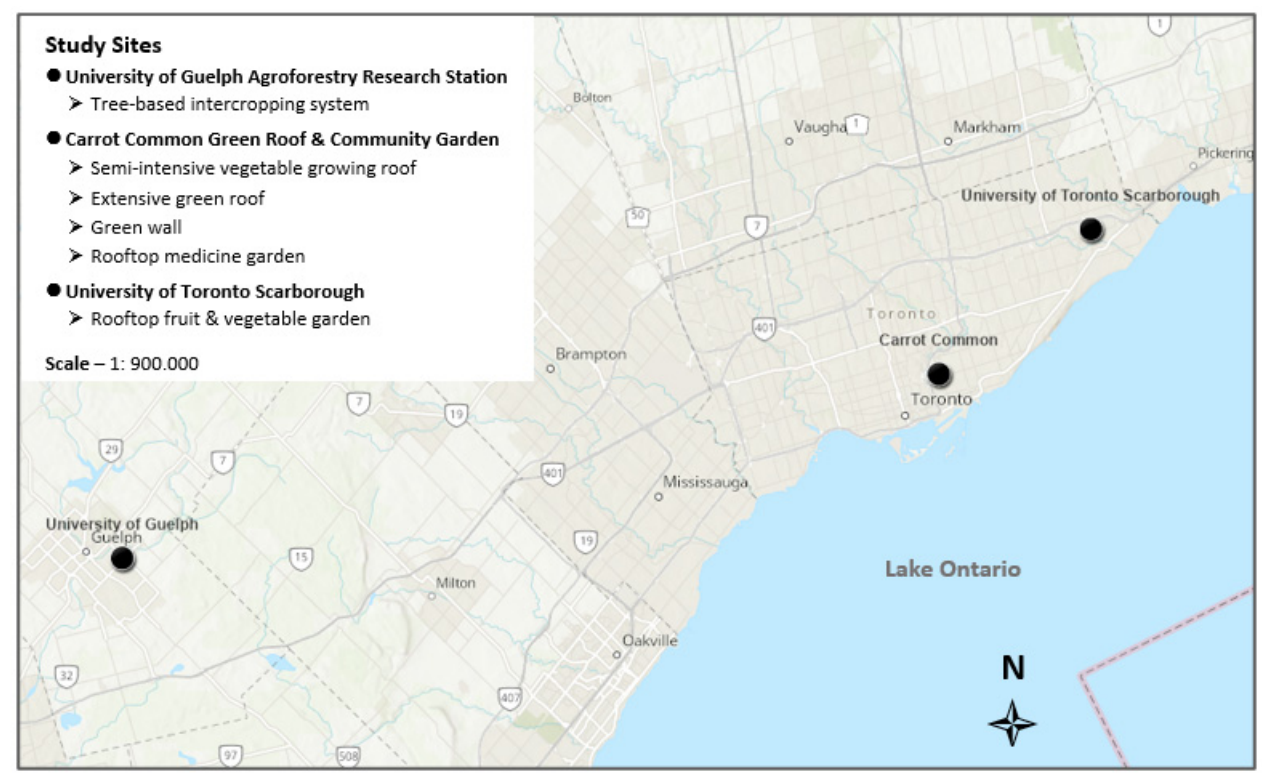

Figure 2. Map of field study sites.

Data collection was undertaken to measure the potential of green infrastructure to reduce concentrations of ozone, nitrogen dioxide, and carbon dioxide in agricultural settings. Air quality monitoring occurred from June to October 2017 at each of the three sites for six- to eight-hour periods for five-minute intervals between $8 \mathrm{AM}$ and $6 \mathrm{PM}$. Due to time constraints and the number of locations, monitoring of individual sites and applications occurred three days per month. One site was monitored for multiple green infrastructure applications. Each site was monitored in ten-day intervals for a representative monthly sample of ozone, nitrogen dioxide, and carbon dioxide concentrations. Testing and calibration were undertaken during the month of June 2017 before data collection commenced [15].

During the data collection campaign, two locations were set up at each site to establish a control and a test position for the monitors. Control and test positions for each site were established approximately 30 to 50 meters apart at the same elevation, to minimize any influence on the control positions from the treatment areas. Three portable monitors were placed at a designated control position and another three identical monitors were set up at a designated test position. Measurements of ozone, nitrogen dioxide, carbon dioxide, temperature, and relative humidity were undertaken simultaneously. Monitors were placed directly on or near the control surface or green infrastructure treatment to capture air flow across the monitor. Air pollutant monitors were placed in the same area and direction, side by side with a space of approximately 15 centimeters between each monitor [15].

Aeroqual (S500 model) portable air-sampling monitors with gas and temperature and relative humidity sensors were used to collect measurements of air pollutants (i.e., ozone and nitrogen dioxide) and carbon dioxide concentrations, in addition to measuring temperature and relative humidity. The Aeroqual portable monitors each have an internal fan that draws air across the gas sensor every sixty seconds. Detection limits for the Aeroqual S500 model portable monitors and individual gas sensors range from 0 to $2000 \mathrm{ppm}$, with a minimum detection limit of $10 \mathrm{ppm}$, for the carbon dioxide sensor; 0 to $1 \mathrm{ppm}$, with a minimum detection limit of $0.005 \mathrm{ppm}$, for the nitrogen dioxide sensor; and 0 to $0.15 \mathrm{ppm}$, with a minimum detection limit of $0.001 \mathrm{ppm}$, for the ozone sensor. Operational temperatures for the Aeroqual S500 model portable monitors and gas sensors range from 0 to $40{ }^{\circ} \mathrm{C}$ [15]. 
Aeroqual portable monitors and gas sensors represent advancements in technology that are increasingly used by researchers to monitor, measure, and study air quality [60]. The U.S. Environmental Protection Agency recently entered into a Cooperative Research and Development Agreement with Aeroqual to investigate new applications, methodologies, and technologies for the low-cost measurement of air pollutants [60]. Aeroqual monitors were selected for use in this field study because of portability, ease of configuration, and affordability compared to conventional air quality monitoring stations that only provide limited access to specialists [15].

\section{Results}

The data collected were used to evaluate the potential impact of productive green infrastructure to reduce ozone, nitrogen dioxide, and carbon dioxide concentrations in agriculture settings.

\subsection{Reduction in Air Pollutants-Ozone}

Across all sites and green infrastructure applications, there was an observed reduction in ozone in most instances, with an average reduction of 0.02 parts per million (ppm) for the monitoring period of June to October 2017, as shown in Figure 3.

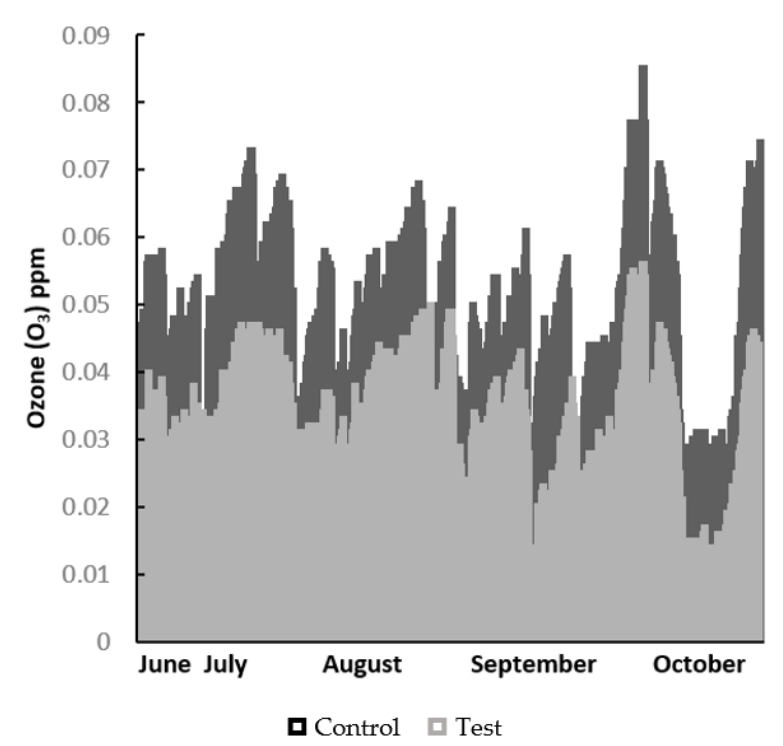

Figure 3. Difference (ppm) between test and control sites for ozone $\left(\mathrm{O}_{3}\right)$, June to October 2017 .

There was an observed reduction in ozone across all sites and applications of green infrastructure, with an average of $0.02 \mathrm{ppm}$ (Figure 4 ) representing an average reduction of 34 percent resulting from the application of agricultural green infrastructure (Figure 3). This reduction is slightly higher than that reported in Anderson and Gough (2020) for the aggregated productive and non-productive green infrastructure applications (31\%). Comparing the two application types using a student $t$-test showed no statistically significant difference between productive and non-productive applications of green infrastructure.

\subsection{Analysis of Reduction in Pollutants-Ozone}

The daily average of the ozone test values is less than the control values when monitoring took place. The errors bars in Figure 5 are five percent of the measured value, which is consistent with the detection limits of the instrumentation.

A $t$-test was conducted for the test and control pair at each site, yielding a $p$ value below the 0.001 margin of error, indicating there is a statistically significant difference in ozone between the means of the test and control for all applications of green infrastructure. 


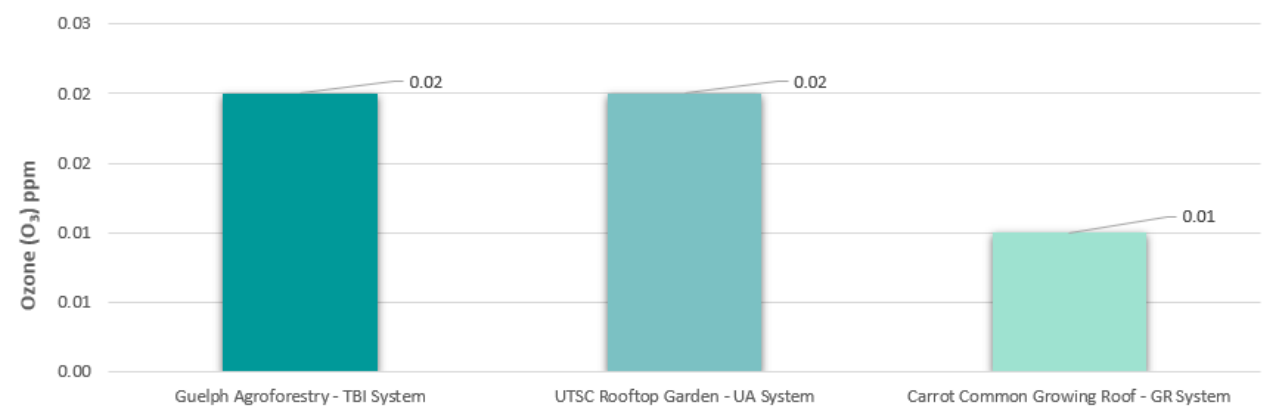

Figure 4. Average ozone $\left(\mathrm{O}_{3}\right)$ reduction in parts per millions (ppm) from June to October 2017-Treebased Intercropping (TBI) System: Guelph Agroforestry Research Station; Urban Agriculture (UA) Systems: UTSC Rooftop Garden; and Green Roof (GR) Systems: Carrot Common Growing Roof.

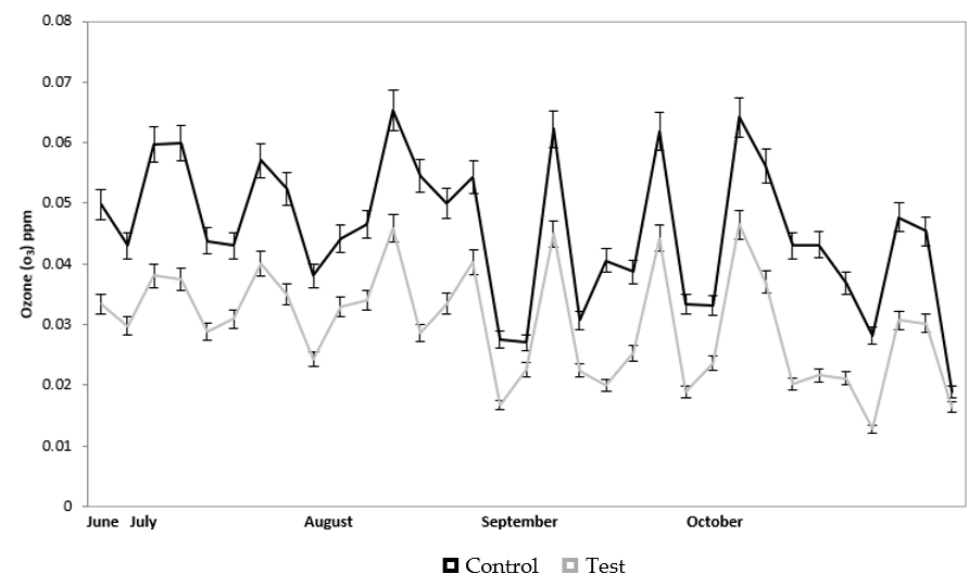

Figure 5. Daily average ozone (ppm) for test and control across all sites from June to October 2017.

\subsection{Reduction in Air Pollutants—Nitrogen Dioxide}

Across all sites and green infrastructure applications, there was an observed reduction in nitrogen dioxide in most all instances, with an average reduction of 0.11 parts per million (ppm) for the monitoring period of June to October 2017, as shown in Figure 6.

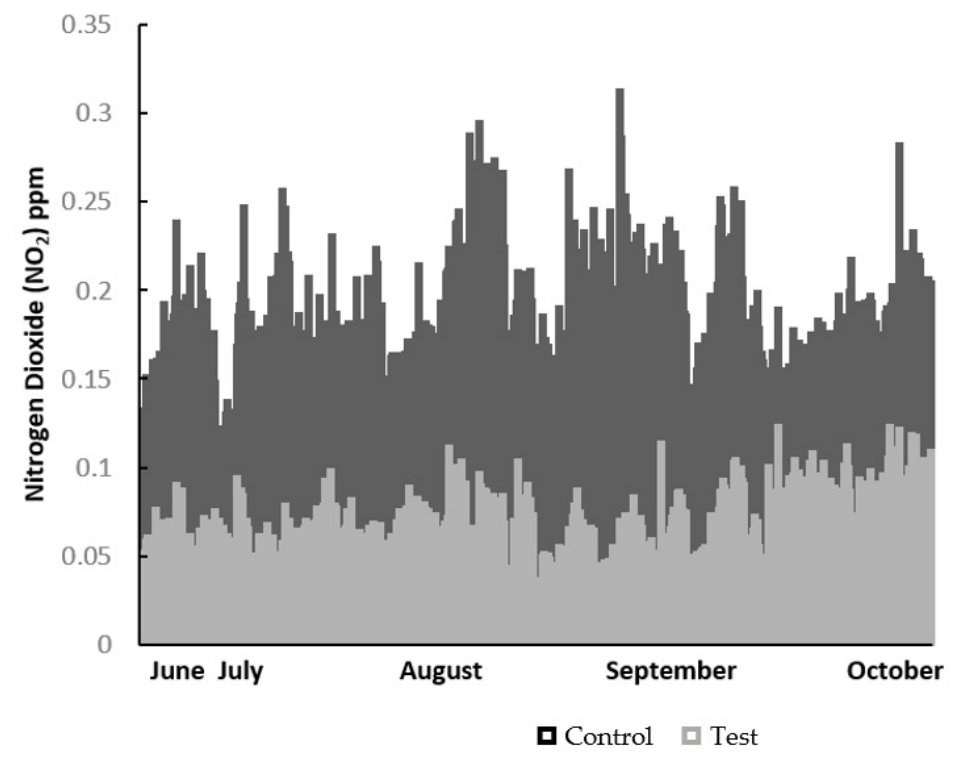

Figure 6. Difference ( $\mathrm{ppm})$ between test and control sites for nitrogen dioxide $\left(\mathrm{NO}_{2}\right)$, June to October 2017. 
There was an observed reduction in nitrogen dioxide across all sites and applications of green infrastructure, with an average of $0.11 \mathrm{ppm}$ (Figure 7) representing an average reduction of 67 percent resulting from the application of productive green infrastructure (Figure 6). This reduction in nitrogen dioxide is slightly higher than that reported in Anderson and Gough (2020) for the aggregated productive and non-productive green infrastructure applications (65\%). Comparing the two application types using a student $t$-test showed no statistically significant difference between productive and non-productive applications of green infrastructure.

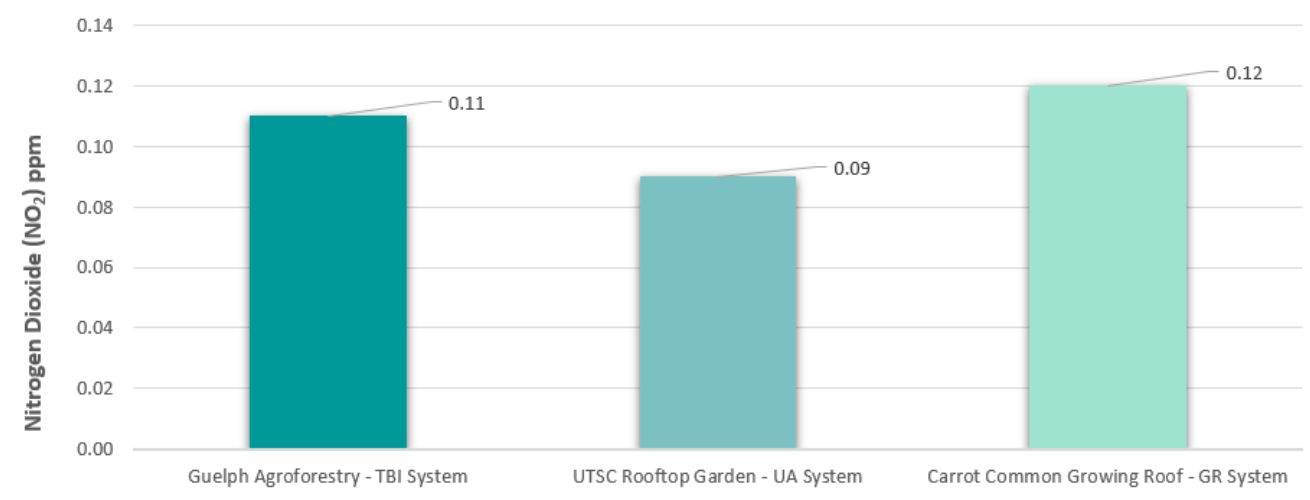

Figure 7. Average nitrogen dioxide $\left(\mathrm{NO}_{2}\right)$ reduction in parts per millions (ppm) from June to October 2017-Tree-based Intercropping (TBI) System: Guelph Agroforestry Research Station; Urban Agriculture (UA) Systems: UTSC Rooftop Garden; and Green Roof (GR) Systems: Carrot Common Growing Roof.

\subsection{Analysis of Reduction in Air Pollutants-Nitrogen Dioxide}

The daily average of the nitrogen dioxide test values is less than the control values when monitoring took place. The errors bars in Figure 8 are five percent of the measured value, which is consistent with the detection limits of the instrumentation.

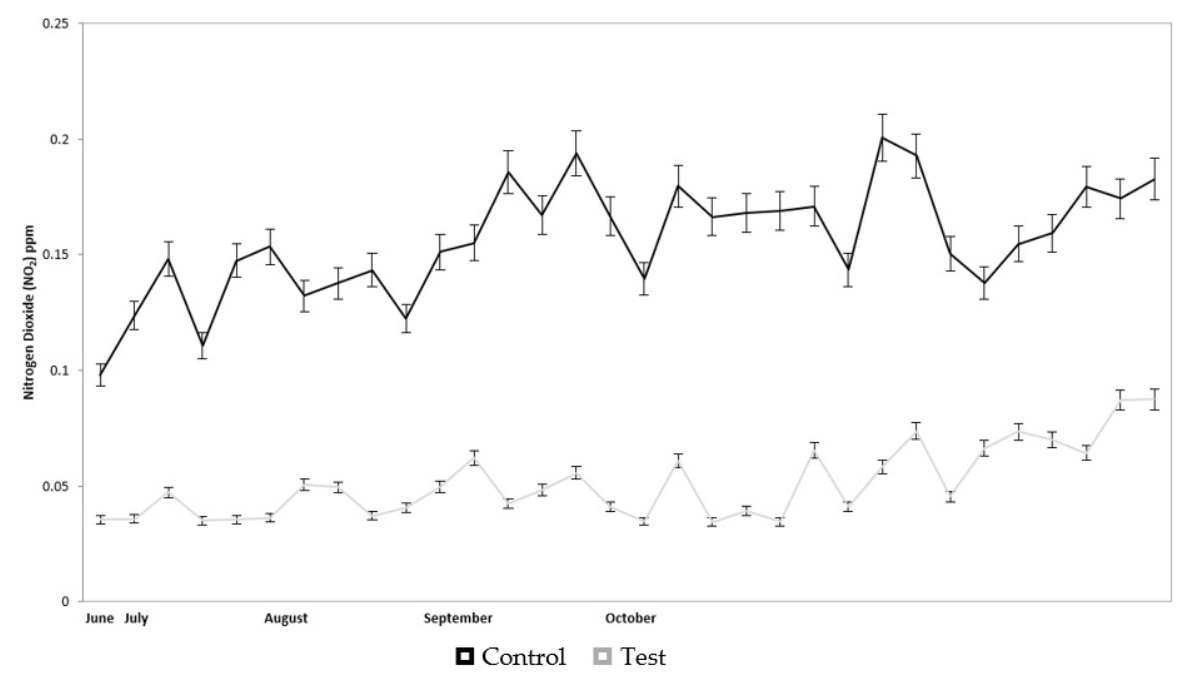

Figure 8. Daily average nitrogen dioxide (ppm) for test and control across all sites, June to October 2017.

A $t$-test was conducted for the test and control pair at each site, yielding a $p$ value below the 0.001 margin of error, indicating there is a statistically significant difference in nitrogen dioxide between the means of the test and control for all applications of green infrastructure. 


\subsection{Reduction in Carbon Dioxide Concentrations}

There was an average reduction in carbon dioxide concentrations across all sites and green infrastructure applications of $20.01 \mathrm{ppm}$ for the monitoring period of June to October 2017, as shown in Figure 9.

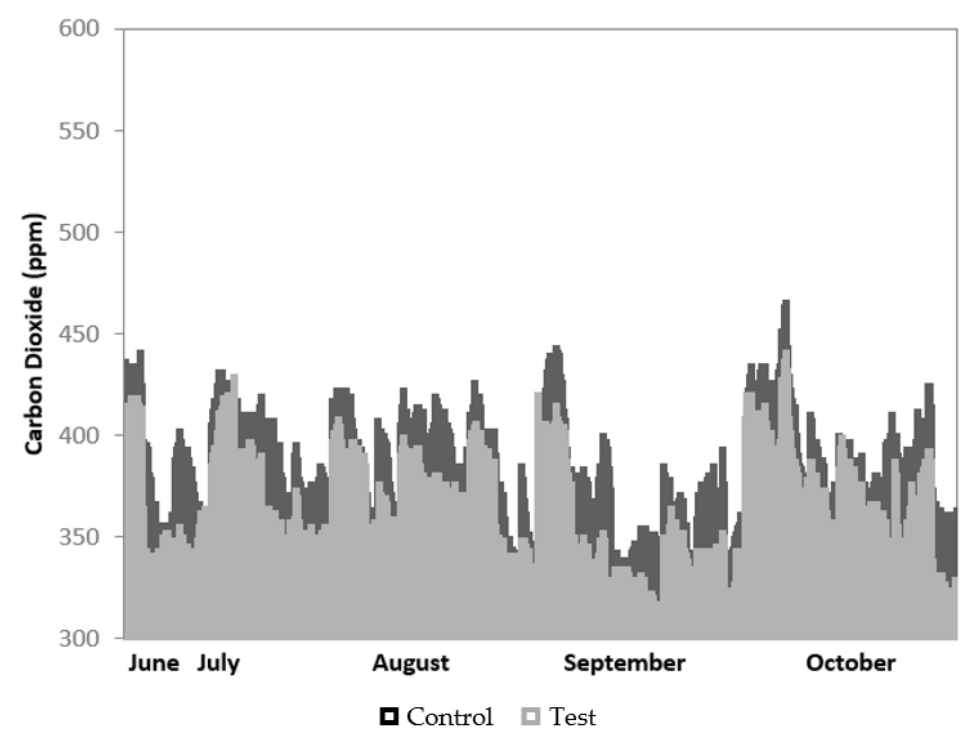

Figure 9. Difference (ppm) between test and control sites for carbon dioxide $\left(\mathrm{CO}_{2}\right)$, June to October 2017.

There was an observed reduction in carbon dioxide across the three productive sites and green infrastructure types, with an average of $20.01 \mathrm{ppm}$ (Figure 10) representing an average reduction of 5 percent resulting from the application of agricultural green infrastructure (Figure 9). This reduction in carbon dioxide is only slightly lower than that reported in Anderson and Gough (2020) for the aggregated productive and nonproductive green infrastructure applications $(6 \%)$. Comparing the two application types using a student $t$-test showed no statistically significant difference between productive and non-productive applications of green infrastructure.

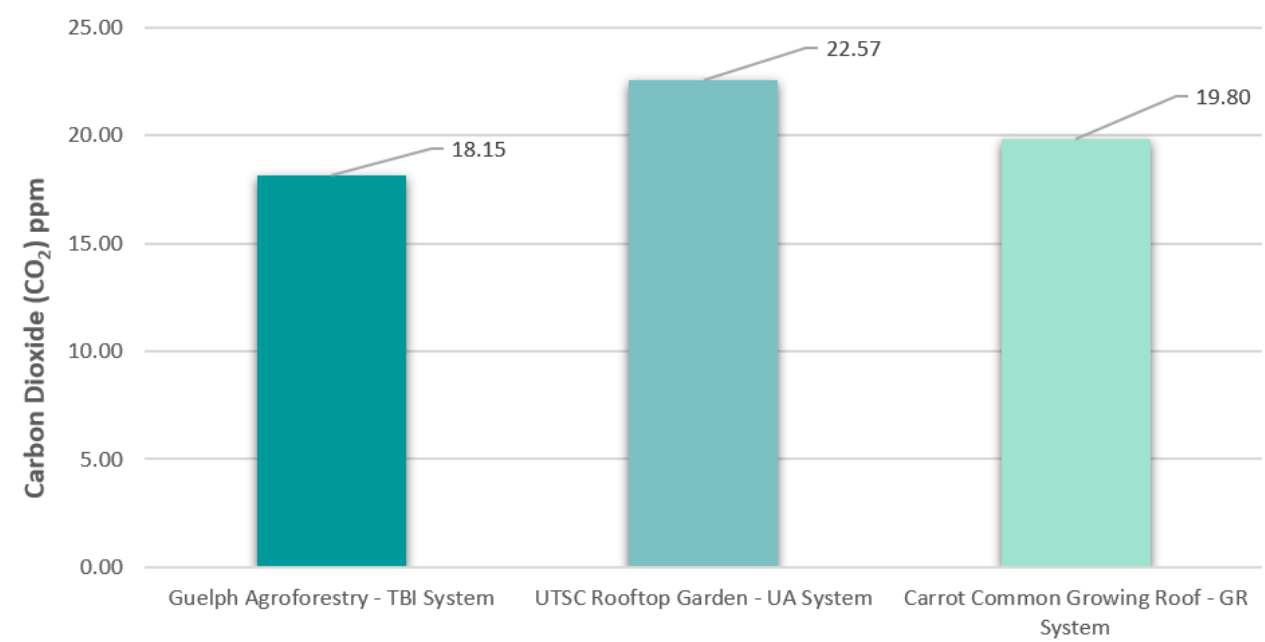

Figure 10. Average nitrogen dioxide $\left(\mathrm{CO}_{2}\right)$ reduction in parts per millions (ppm) from June to October 2017-Tree-based Intercropping (TBI) System: Guelph Agroforestry Research Station; Urban Agriculture (UA) Systems: UTSC Rooftop Garden; and Green Roof (GR) Systems: Carrot Common Growing Roof. 


\subsection{Analysis of Reduction in Carbon Dioxide Concentrations}

The daily average of the carbon dioxide test values is less than the control values when monitoring took place. The errors bars in Figure 11 are five percent of the measured value, which is consistent with the detection limits of the instrumentation.

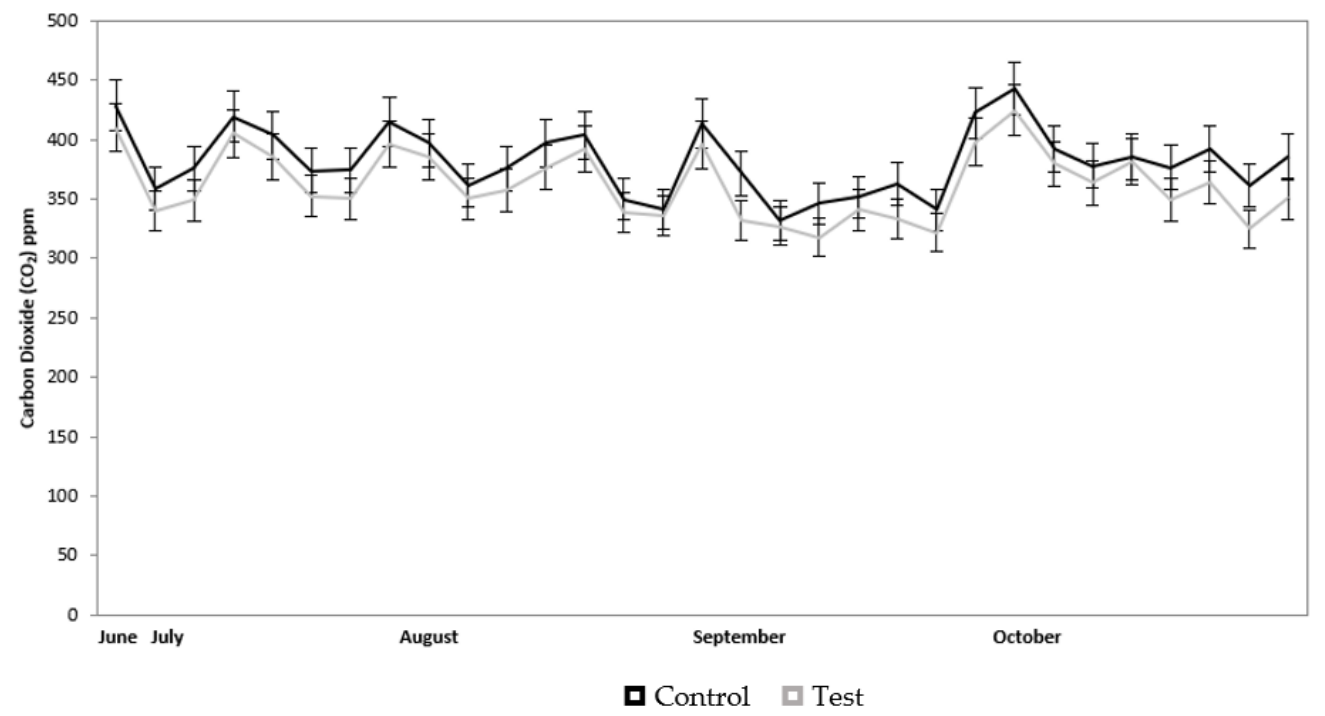

Figure 11. Daily average carbon dioxide (ppm) for test and control across all sites, June to October 2017.

A $t$-test was conducted for the test and control pair at each site, yielding a $p$ value below the 0.001 margin of error, indicating there is a statistically significant difference in carbon dioxide between the means of the test and control for all applications of productive green infrastructure.

\section{Discussion}

The new findings and analysis of the field data collected [15] are consistent with the hypothesis that productive green infrastructure types are as effective in reducing ozone and nitrogen dioxide pollution and providing carbon sequestration capacity across different agricultural morphologies in Ontario, Canada, as non-productive forms of green infrastructure in the same area. Productive green infrastructure reduces air and greenhouse gas pollutants independent of location, urban or rural. This was illustrated in the statistical analysis, indicating that there is no statistically significant difference between applications of productive and non-productive applications of green infrastructure.

While the findings of this field study were limited to one summer season, they show the application of productive green infrastructure across different agricultural morphologies is as effective in air pollution abatement and GHG emissions reduction as other types of non-productive green infrastructure. This study is novel because it uniquely shows the potential air pollution abatement benefits of productive green infrastructure applications in different agricultural settings. This research also shows the potential of productive green infrastructure applications to reduce agricultural point source emissions. Although there are multiple studies which evaluate the potential of specific applications of green infrastructure such as trees, shrubs, and green roofs to reduce individual air pollutants, few studies specifically evaluate productive green infrastructure applications.

Compared to other studies, the results of this analysis are novel because multiple types of productive green infrastructure were applied in a controlled field experiment across three different agricultural morphologies. Statistical analysis confirms the observed reduction in ozone and nitrogen dioxide. The results indicate that the different productive green infrastructure applications are all beneficial in reducing air pollution from ozone and nitrogen dioxide and are not limited to either specific applications such as trees, or specific 
land use types. Productive applications are statistically as effective in reducing ozone and nitrogen dioxide as non-productive applications of green infrastructure.

In this controlled field study, all three productive green infrastructure applications demonstrated a positive impact on carbon dioxide concentrations in different agricultural settings. Statistical analysis confirms the observed reduction in carbon dioxide. Productive applications did not differ statistically from non-productive green infrastructure applications.

Other studies of carbon sequestration potential in specific applications of green infrastructure include Whittinghill et al., (2014) which evaluated the potential of productive and non-productive green roof and ornamental landscape systems to sequester carbon dioxide in above- and below-ground biomass using field measurements. Findings from this study showed an increase in the total carbon content of the green roof systems of up to 81 percent over a one-year period in Michigan [53]. Green roof systems in this study used different plant varietals including herbaceous perennials, grasses, vegetables, and herbs [53]. Thevathasan and Gordon (2004) evaluated the capacity of tree-based intercropping systems to sequester carbon. Findings from this study showed that carbon sequestration potential in fast-growing, tree-based intercropping systems was four times more than in conventional agricultural fields in southern Ontario [20]. Wotherspoon et al., (2014) evaluated the carbon sequestration potential of five tree species in a 25-year-old temperate tree-based intercropping system in southern Ontario. Findings from this study showed greater atmospheric $\mathrm{CO}_{2}$ sequestration potential for all five tree species when compared with a conventional agricultural system [30].

Compared with these previous studies, the results of this particular analysis are novel, because multiple types of productive green infrastructure were assessed in a controlled field experiment across three different agricultural morphologies. Observations from this new analysis indicate that different types of productive green infrastructure are beneficial in reducing carbon dioxide concentrations in agricultural systems and are not limited to specific applications such as trees, noting that two of the three productive study sites did not contain trees. In addition, observations indicate the application of productive green infrastructure is beneficial across different land use types. This illustrates that productive applications are as effective in reducing carbon dioxide as non-productive applications of green infrastructure.

Productive green infrastructure can build climate resilience into agricultural systems through supply-side mitigation and adaptation. It provides an effective supply-side form of climate change mitigation by reducing air pollutants such as nitrogen dioxide, and greenhouse gas pollutants such as ozone and carbon dioxide. Because agricultural production has such a significant impact on anthropogenic emissions, the wide adoption of multiple productive green infrastructure applications is essential for reducing greenhouse gas emissions, decarbonizing the production process through improved carbon sequestration capacity, and building climate resilience through non-provisioning and provisioning ecosystem services. The broad application of productive green infrastructure has the capacity to function as an effective supply-side intervention for climate change adaptation by improving soil health, increasing biodiversity, and managing stormwater.

\section{Conclusions}

The new findings and analysis from this previously reported field work [15], while limited to one summer season, provide comprehensive insight into the positive impact of multiple productive green infrastructure applications on air pollution abatement and carbon dioxide concentrations, similar to non-productive applications. Productive green infrastructure provides a versatile nature-based solution to the challenges presented by different agricultural morphologies in a changing climate.

Author Contributions: V.A. and W.A.G. contributed to the study conception and design. Material preparation: data collection and analysis were performed by V.A. The first draft of the manuscript was written by V.A. and W.A.G. contributed to the editing process. All authors have read and agreed to the published version of the manuscript. 
Funding: The authors are supported by W.A.G.'s Natural Sciences and Engineering Research Council of Canada (NSERC) Grant RGPIN-2018-06801.

Institutional Review Board Statement: Not applicable.

Informed Consent Statement: Not applicable.

Data Availability Statement: Available upon request.

Acknowledgments: The authors wish to thank the Seeds of Hope Foundation and the Guelph Agroforestry Research Station for providing site access.

Conflicts of Interest: The authors declare no conflict of interest.

\section{References}

1. Smith, P.; Bustamante, M.; Ahammad, H.; Clark, H.; Dong, H.; Elsiddig, E.A.; Haberl, H.; Harper, R.; House, J.; Jafari, M.; et al. Agriculture, Forestry and Other Land Use (AFOLU). In Climate Change 2014: Mitigation of Climate Change. Contribution of Working Group III to the Fifth Assessment Report of the Intergovernmental Panel on Climate Change; Edenhofer, O., Pichs-Madruga, R., Sokona, Y., Farahani, E., Kadner, S., Seyboth, K., Adler, A., Baum, I., Brunner, S., Eickemeier, P., et al., Eds.; Cambridge University Press: Cambridge, UK; New York, NY, USA, 2014.

2. Environmental Commissioner of Ontario. Facing Climate Change: Greenhouse Gas Progress Report. Available online: http: / / docs.assets.eco.on.ca/reports/climate-change/2015/2015-GHG.pdf (accessed on 1 June 2021).

3. Lucon, O.; Ürge-Vorsatz, D.; Zain Ahmed, A.; Akbari, H.; Bertoldi, P.; Cabeza, L.F.; Eyre, N.; Gadgil, A.; Harvey, L.D.D.; Jiang, Y.; et al. Buildings. In Climate Change 2014: Mitigation of Climate Change. Contribution of Working Group III to the Fifth Assessment Report of the Intergovernmental Panel on Climate Change; Edenhofer, O., Pichs-Madruga, R., Sokona, Y., Farahani, E., Kadner, S., Seyboth, K., Adler, A., Baum, I., Brunner, S., Eickemeier, P., et al., Eds.; Cambridge University Press: Cambridge, UK; New York, NY, USA, 2014.

4. $\quad$ Stocker, T.F.; Qin, D.; Plattner, G.-K.; Alexander, L.V.; Allen, S.K.; Bindoff, N.L.; Bréon, F.-M.; Church, J.A.; Cubasch, U.; Emori, S.; et al. Technical Summary. In Climate Change 2013: The Physical Science Basis. Contribution of Working Group I to the Fifth Assessment Report of the Intergovernmental Panel on Climate Change; Stocker, T.F., Qin, D., Plattner, G.-K., Tignor, M., Allen, S.K., Boschung, J., Nauels, A., Xia, Y., Bex, V., Midgley, P.M., Eds.; Cambridge University Press: Cambridge, UK; New York, NY, USA, 2013.

5. Fiore, A.M.; Naik, V.; Leibensperger, E.M. Air Quality and Climate Connections. J. Air Waste Manag. Assoc. 2015, 65, 645-685. [CrossRef] [PubMed]

6. Jacob, D.J.; Winner, D.A. Effect of climate change on air quality. Atmos. Environ. 2009, 43, 51-63. [CrossRef]

7. Weaver, C.; Liang, X.-Z.; Zhu, J.; Adams, P.J.; Amar, P.; Avise, J.; Caughey, M.; Chen, J.; Cohen, R.C.; Cooter, E.; et al. A Preliminary Synthesis of Modeled Climate Change Impacts on U.S. Regional Ozone Concentrations. Bull. Am. Meteorol. Soc. 2009, 90, 1843-1864. [CrossRef]

8. Ordóñez, C.; Mathis, H.; Furger, M.; Henne, S.; Hüglin, C.; Staehelin, J.; Prévôt, A.S.H. Changes of daily surface ozone maxima in Switzerland in all seasons from 1992 to 2002 and discussion of summer. Atmos. Chem. Phys. Discuss. 2005, 5, 1187-1203. [CrossRef]

9. Tressol, M.; Ordonez, C.; Zbinden, R.; Brioude, J.; Thouret, V.; Mari, C.; Nedelec, P.; Cammas, J.-P.; Smit, H.; Pätz, H.-W.; et al. Air pollution during the 2003 European heat wave as seen by MOZAIC airliners. Atmos. Chem. Phys. Discuss. 2008, 8, $2133-2150$. [CrossRef]

10. Vieno, M.; Dore, A.J.; Stevenson, D.S.; Doherty, R.; Heal, M.R.; Reis, S.; Hallsworth, S.; Tarrason, L.; Wind, P.; Fowler, D.; et al. Modelling surface ozone during the 2003 heat-wave in the UK. Atmos. Chem. Phys. Discuss. 2010, 10, 7963-7978. [CrossRef]

11. Cohen-Shacham, E.; Walters, G.; Janzen, C.; Maginnis, S. Nature-Based Solutions to Address Global Societal Challenges; IUCN: Gland, Switzerland, 2016.

12. Cohen-Shacham, E.; Andrade, A.; Dalton, J.; Dudley, N.; Jones, M.; Kumar, C.; Maginnis, S.; Maynard, S.; Nelson, C.R.; Renaud, F.G.; et al. Core principles for successfully implementing and upscaling Nature-based Solutions. Environ. Sci. Policy 2019, 98, 20-29. [CrossRef]

13. Seddon, N.; Chausson, A.; Berry, P.; Girardin, C.A.J.; Smith, A.; Turner, B. Understanding the value and limits of nature-based solutions to climate change and other global challenges. Philos. Trans. R. Soc. B Biol. Sci. 2020, 375, 20190120. [CrossRef] [PubMed]

14. Anderson, V. Deep Adaptation: A Framework for Climate Resilience, Decarbonization and Planetary Health. Ph.D. Thesis, University of Toronto, Toronto, ON, Canada, 2018. Available online: https:/ /tspace.library.utoronto.ca/ (accessed on 1 June 2021).

15. Anderson, V.; Gough, W.A. Evaluating the potential of nature-based solutions to reduce ozone, nitrogen dioxide, and carbon dioxide through a multi-type green infrastructure study in Ontario, Canada. City Environ. Interact. 2020, 6, 100043. [CrossRef]

16. Anderson, V.; Gough, W.A. Nature-based cooling potential: A multi-type green infrastructure evaluation in Toronto, Ontario, Canada. Int. J. Biometeorol. 2021, 6, 1-13. [CrossRef]

17. Anderson, V.; Gough, W. Harnessing the Four Horsemen of Climate Change: A Framework for Deep Resilience, Decarbonization, and Planetary Health in Ontario, Canada. Sustainability 2021, 13, 379. [CrossRef]

18. Anderson, V.; Gough, W.A. Form, function, and nomenclature: Deconstructing green infrastructure and its role in a changing climate. In Climate Change and Extreme Events; Elsevier BV: Amsterdam, The Netherlands, 2021; pp. $125-144$. 
19. Anderson, V.; Gough, W.; Agic, B. Nature-Based Equity: An Assessment of the Public Health Impacts of Green Infrastructure in Ontario Canada. Int. J. Environ. Res. Public Health 2021, 18, 5763. [CrossRef]

20. Thevathasan, N.V.; Gordon, A.M. Ecology of tree intercropping systems in the North temperate region: Experiences from southern Ontario, Canada. Adv. Agrofor. 2004, 61, 257-268. [CrossRef]

21. Jose, S. Agroforestry for ecosystem services and environmental benefits: An overview. Agrofor. Syst. 2009, 76, 1-10. [CrossRef]

22. Evers, A.K.; Bambrick, A.; Lacombe, S.; Dougherty, M.C.; Peichl, M.; Gordon, A.M.; Thevathasan, N.V.; Whalen, J.; Bradley, R.L. Potential Greenhouse Gas Mitigation through Temperate Tree-Based Intercropping Systems. Open Agric. J. $2010,4,49-57$. [CrossRef]

23. Thevathasan, N.V.; Coleman, B.; Zabek, L.; Ward, T.; Gordon, A.M. Agroforestry in Canada and its role in farming systems. In Temperate Agroforestry Systems; Gordon, A.M., Newman, S.M., Coleman, B.R.W., Eds.; CABI Publishing: Wallingford, UK, 2018; pp. 7-49. [CrossRef]

24. Rowe, D.B. Green roofs as a means of pollution abatement. Environ. Pollut. 2011, 159, 2100-2110. [CrossRef] [PubMed]

25. Plascencia-Escalante, F. An analysis of some components of the nitrogen cycle as affected by land use adjacent to the riparian zone of a Southern Ontario stream. Ph.D. Thesis, University of Guelph, Guelph, ON, Canada, 2008.

26. Lin, B.; Philpott, S.; Jha, S. The future of urban agriculture and biodiversity-ecosystem services: Challenges and next steps. Basic Appl. Ecol. 2015, 16, 189-201. [CrossRef]

27. Hillel, D.; Rosenzweig, C. Biodiversity and food production. In Sustaining Life: How Human Health Depends on Biodiversity; Chivian, E., Bernstein, A., Eds.; Oxford University Press: New York, NY, USA, 2008; pp. 325-381.

28. Coutts, C.; Hahn, M. Green Infrastructure, Ecosystem Services, and Human Health. Int. J. Environ. Res. Public Health 2015, 12, 9768-9798. [CrossRef]

29. Thevathasan, N.V.; Gordon, A.M.; Bradley, R.; Cogliastro, A.; Folkard, P.; Grant, R.; Kort, J.; Liggins, L.; Njenga, F.; Olivier, A.; et al. Agroforestry Research and Development in Canada: The Way Forward. In Agroforestry-The Future of Global Land Use; Springer: Dordrecht, The Netherlands, 2012; pp. 247-283. [CrossRef]

30. Wotherspoon, A.; Thevathasan, N.V.; Gordon, A.M.; Voroney, R.P. Carbon sequestration potential of five tree species in a 25-year-old temperate tree-based intercropping system in southern Ontario, Canada. Agrofor. Syst. 2014, 88, 631-643. [CrossRef]

31. Oberndorfer, E.; Lundholm, J.; Bass, B.; Coffman, R.R.; Doshi, H.; Dunnett, N.; Gaffin, S.; Köhler, M.; Liu, K.K.Y.; Rowe, B. Green Roofs as Urban Ecosystems: Ecological Structures, Functions, and Services. Bioscience 2007, 57, 823-833. [CrossRef]

32. Parkins, K.; Clark, J. Green roofs provide habitat for urban bats. Glob. Ecol. Conserv. 2015, 4, 349-357. [CrossRef]

33. Tonietto, R.; Fant, J.; Ascher, J.; Ellis, K.; Larkin, D. A comparison of bee communities of Chicago green roofs, parks and prairies. Landsc. Urban Plan. 2011, 103, 102-108. [CrossRef]

34. Hedin, L.O. Deposition of Nutrients and Pollutants to Ecosystems. In Methods in Ecosystem Science; Springer: New York, NY, USA, 2000; pp. 265-276.

35. Nowak, D.J.; Crane, D.E.; Stevens, J.C. Air pollution removal by urban trees and shrubs in the United States. Urban For. Urban Green. 2006, 4, 115-123. [CrossRef]

36. Kleerekoper, L.; Esch, M.P.-V.; Salcedo, T.B. How to make a city climate-proof, addressing the urban heat island effect. Resour. Conserv. Recycl. 2012, 64, 30-38. [CrossRef]

37. Rao, M.; George, L.A.; Rosenstiel, T.N.; Shandas, V.; Dinno, A. Assessing the relationship among urban trees, nitrogen dioxide, and respiratory health. Environ. Pollut. 2014, 194, 96-104. [CrossRef]

38. King, K.L.; Johnson, S.; Kheirbek, I.; Lu, J.W.; Matte, T. Differences in magnitude and spatial distribution of urban forest pollution deposition rates, air pollution emissions, and ambient neighborhood air quality in New York City. Landsc. Urban Plan. 2014, 128, 14-22. [CrossRef]

39. Gourdji, S. Review of plants to mitigate particulate matter, ozone as well as nitrogen dioxide air pollutants and applicable recommendations for green roofs in Montreal, Quebec. Environ. Pollut. 2018, 241, 378-387. [CrossRef]

40. Nowak, D.J.; Hirabayashi, S.; Doyle, M.; McGovern, M.; Pasher, J. Air pollution removal by urban forests in Canada and its effect on air quality and human health. Urban For. Urban Green. 2018, 29, 40-48. [CrossRef]

41. Sicard, P.; Agathokleous, E.; Araminiene, V.; Carrari, E.; Hoshika, Y.; De Marco, A.; Paoletti, E. Should we see urban trees as effective solutions to reduce increasing ozone levels in cities? Environ. Pollut. 2018, 243, 163-176. [CrossRef]

42. Yang, J.; Yu, Q.; Gong, P. Quantifying air pollution removal by green roofs in Chicago. Atmos. Environ. 2008, $42,7266-7273$. [CrossRef]

43. Baik, J.-J.; Kwak, K.-H.; Park, S.-B.; Ryu, Y.-H. Effects of building roof greening on air quality in street canyons. Atmos. Environ. 2012, 61, 48-55. [CrossRef]

44. Vos, P.E.; Maiheu, B.; Vankerkom, J.; Janssen, S. Improving local air quality in cities: To tree or not to tree? Environ. Pollut. 2013, 183, 113-122. [CrossRef] [PubMed]

45. Bottalico, F.; Chirici, G.; Giannetti, F.; De Marco, A.; Nocentini, S.; Paoletti, E.; Salbitano, F.; Sanesi, G.; Serenelli, C.; Travaglini, D. Air Pollution Removal by Green Infrastructures and Urban Forests in the City of Florence. Agric. Agric. Sci. Procedia 2016, 8 , 243-251. [CrossRef]

46. Tan, P.Y.; Sia, A. A pilot green roof research project in Singapore. In Proceedings of the Third Annual Greening Rooftops for Sustainable Communities Conference, Awards and Trade Show, Washington, DC, USA, 4-6 May 2005. 
47. Speak, A.; Rothwell, J.; Lindley, S.; Smith, C. Urban particulate pollution reduction by four species of green roof vegetation in a UK city. Atmos. Environ. 2012, 61, 283-293. [CrossRef]

48. Abhijith, K.; Kumar, P.; Gallagher, J.; McNabola, A.; Baldauf, R.; Pilla, F.; Broderick, B.; DI Sabatino, S.; Pulvirenti, B. Air pollution abatement performances of green infrastructure in open road and built-up street canyon environments-A review. Atmos. Environ. 2017, 162, 71-86. [CrossRef]

49. Janhäll, S. Review on urban vegetation and particle air pollution-Deposition and dispersion. Atmos. Environ. 2015, 105, 130-137. [CrossRef]

50. Abjihith, K.V.; Kumar, P. Field investigations for evaluating green infrastructure effects on air quality in open-road conditions. Atmos. Environ. 2019, 201, 132-147. [CrossRef]

51. Taleghani, M.; Clark, A.; Swan, W.; Mohegh, A. Air pollution in a microclimate; the impact of different green barriers on the dispersion. Sci. Total Environ. 2020, 711, 134649. [CrossRef]

52. Demuzere, M.; Orru, K.; Heidrich, O.; Olazabal, E.; Geneletti, D.; Orru, H.; Bhave, A.G.; Mittal, N.; Feliu, E.; Faehnle, M. Mitigating and adapting to climate change: Multi-functional and multi-scale assessment of green urban infrastructure. J. Environ. Manag. 2014, 146, 107-115. [CrossRef] [PubMed]

53. Whittinghill, L.J.; Rowe, D.B.; Schutzki, R.; Cregg, B.M. Quantifying carbon sequestration systems of various green roof and ornamental landscape sys-tems. Landsc. Urban Plan. 2014, 123, 41-48. [CrossRef]

54. Li, J.-F.; Wai, O.W.; Li, Y.; Zhan, J.-M.; Ho, Y.A.; Li, J.; Lam, E.S.S. Effect of green roof on ambient CO2 concentration. Build. Environ. 2010, 45, 2644-2651. [CrossRef]

55. Velasco, E.; Roth, M.; Norford, L.; Molina, L.T. Does urban vegetation enhance carbon sequestration? Landsc. Urban Plan. 2016, 148, 99-107. [CrossRef]

56. Montagnini, F.; Nair, P.K.R. Carbon sequestration: An underexploited environmental benefit of agroforestry systems. Adv. Agrofor. 2004, 61, 281-295. [CrossRef]

57. Peichl, M.; Thevathasan, N.V.; Gordon, A.M.; Huss, J.; Abohassan, R.A. Carbon Sequestration Potentials in Temperate Tree-Based Intercropping Systems, Southern Ontario, Canada. Agrofor. Syst. 2006, 66, 243-257. [CrossRef]

58. Berardi, U.; Amir Hosein, G.H.; Ali, G. State-of-the-art analysis of the environmental benefits of green roofs. Appl. Energy 2014, 15, 411-428. [CrossRef]

59. Thornbush, M. Urban agriculture in the transition to low carbon cities through urban greening. AIMS Environ. Sci. 2015, 2, 852-867. [CrossRef]

60. Environmental Protection Agency (EPA). EPA Combines Expertise with New Zealand Company to Advance Air Sensor Technologies. 2019. Available online: https:/ / www.epa.gov/sciencematters/epa-combines-expertise-new-zealand-company-advanceair-sensor-technologies (accessed on 1 June 2021). 